\title{
Optimization of environmental parameters on the decolorization of Reactive Brilliant Blue dye by yeast isolates from textile effluent
}

\author{
Sanaa, M. Ashour ; Hoda, H. Abo- Ghalia and Doaa, S. Abdel maksoud
}

Botany Department, Faculty of Women for Arts, Science and Education- Ain Shams

University

\begin{abstract}
The present study was conducted to investigate the decolorization and degradation of Reactive Brilliant Blue dye using yeasts isolated from the effluent treatment of the textile industries and the identified yeast strains under optimal conditions using the standard methods. Among twenty-four yeast strains, only five yeasts have the ability to decolorize the dye (2.8\%). Three yeast strains; Rhodotorula glutinis, Candida utilis(1) and Candida sphaerica as well as the local two yeast isolates which were identified as Rhodotorula rubra and Cryptococcus albidus showing high decolorization rate, they were used for the decolorization of Reactive Brilliant Blue dye in a medium containing glucose and yeast extract as a best carbon and nitrogen sources, the $\mathrm{pH}$ of medium varied among the yeasts, C. utilis(1), R. rubra and $C$. albidus was 4, while $C$. sphaerica and $R$. glutinis was 6 and5.5, respectively. All yeast strains were incubated for $18 \mathrm{~h}$ at $25^{\circ} \mathrm{C}$ except C. utilis(1) at $37^{\circ} \mathrm{C}$. C. utilis(1), R. glutinis and C. sphaerica showed high decolorization rate under static aerobic conditions. While $R$. rubra and $C$. albidus showed decolorization under static anaerobic conditions. According to the potentiality of yeast strains; $C$. sphaerica could achieved a removal ratio of $68.83 \%$, while $C$. albidus $68.40 \%$, R. rubra $67.75 \%$, R. glutinis $66.88 \%$ and C. utilis(1) $63.85 \%$ of Reactive Brilliant Blue dye in a concentration of $10 \mathrm{mg} / \mathrm{L}$. The highest biodegradation of the dye by the five yeast strains was confirmed by using plain distilled water as a decolorization medium. In conclusion, yeast strains could be used for the biodegradation of dye- polluted waters including rate of degradation of anthraquinone dye.
\end{abstract}

Key words: Yeast- Reactive Brilliant Blue dye- Decolorization- Optimization

Corresponding author: lastmaster 7799@yahoo.com 


\section{Introduction}

Textile dyes are engineered to be resistant to environmental conditions. During recent years the treatment of textile dye effluents has been the focus of significant research because of the potentially low cost of the process (Pajot et al., 2011). Many synthetic dyes belong to xenobiotic chemicals that are degraded with difficulty in nature, and therefore their removal from aqueous effluents from the textile industry has been receiving considerable environment research attention (Borchert and Libra, 2001).Large amount of synthetic structurally varied dyes are being used extensively in textile, paper, printing, leather, paints, plastic, cosmetic, food industries and dye houses due to their ease of production, fastness and color variety as compared to natural dyes(Cristovao et al., 2009; Waghmode et al., 2011). The disposal of the effluent from these industries and dye houses into the environment causes change in $\mathrm{pH}$, increase COD(chemical oxygen demand), TOC(total organic carbon) and also affects photosynthetic activity of aquatic life due to reduced light penetration and gas solubility in water bodies which leads to adverse effects on aquatic life(Aksu and Donmez, 2003; Saratale et al., 2009. A large number of synthetic dyes with specific chemical groups ( azo, acid, base, anthracene, triphenylmethane etc.) are widely used in the textile, cosmetic and pharmaceutical industry( Pavko, 2011), in addition, a significant amount of these compounds are discharged into the environment through effluents (Christiane et al., 2013). Because color in waste water is highly visible and affects esthetics, water transparency and gas solubility in water bodies and especially because many dyes are made from known carcinogens such as benzidine and other aromatic compounds, waste waters with dye have to be treated (Dong $\boldsymbol{e t}$ al., 2003 and Ayed et al., 2011). The presence of very low concentration of dyes in effluent is highly visible and undesirable (Nigam et al., 2000; Robinson et al., 2001).The excessive discharge of the effluents from the textile industries contains toxic chemicals such as azo dyes and reactive dyes which adversely affect the natural resources, soil fertility and aquatic organisms and disturb the integrity of the ecosystem (Puvaneswari et al., 2006 and Sudha $\boldsymbol{e t}$ al., 2014). Conventional wastewater treatment system is inefficient because of the recalcitrant nature of dyes (Waghmode et al., 2011). Existing physical and chemical technologies are expensive, time consuming and produce a large amount of sludge or cause secondary pollution ((Telke et al., 2009 and Tamboli et al., 2010).

Mechanisms of biological decolorization of textile dye depend greatly on the chemical structure of the dye and the microorganisms used (Pajot et al., 2011). Numerous studies have indicated that biodegradation by microorganisms is a promising approach for treating dyes 
contained in wastes (Fu and Viraraghavan, 2001). Over past decades many microorganisms have been found to be capable of degrading dyes; these include bacteria (Sani and Banerjee, 1999), filamentous fungi (Swamy and Ramsay, 1999; Balan and Monteiro, 2001), yeasts (Martorell et al., 2012), actinomycetes (Zhou and Zimmermann, 1993) and algae (Dilek $\boldsymbol{e t}$ al., 1999). filamentous fungi are well recognized for dye decolorization, while the reports on textile dye decolorization mechanisms of yeasts have been scare (Pajot et al., 2011). Fungal ligninolytic enzyme system (lignin peroxidase, manganese peroxidase and laccase) may also be involved in the bio-oxidation of dyes (Gold and Alic, 1993). However, the requirement for low pH (Swamy and Ramsay, 1999) for optimum enzyme activity and the long hydraulic retention time for complete decolorization (Swamy and Ramsay, 1999) are major disadvantages in using fungi. In addition, growth of filamentous fungi is slow compared with most single-cell microorganisms and the production of mycelium often makes filamentous fungi poorly adaptable to wastewater treatments (Yu and Wen, 2005). Compared to bacteria and filamentous fungi, yeasts have many advantages. They are not only grow rapidly like bacteria but also they are filamentous fungi have the ability to resist unfavorable environments (Martorell $\boldsymbol{e t}$ al., 2012). Besides, yeasts have been found to be very efficient in treating high strength organic wastewaters, such as food, molasses and oil manufacture industrial effluents (Yang et al., 2008 and Martorell et al., 2012).

Only a few reports on the degradation of azo dyes or anthraquinone dyes by yeasts have appeared (Yu and wen, 2005; Pajot et al., 2011).

In the present study, we have focused our attention on the use of local yeasts isolated from the effluent treatment of the textile industries. These identified yeast strains were used for the bioremediation purpose, especially for the textile effluent treatment containing Reactive Brilliant Blue as an industrial dye under optimum conditions.

\section{2-Materials and methods}

\subsection{Collection of samples}

The samples were collected from the effluent treatment of the textile industries and soil surrounding areas of Atlas and Miser Spain industries located in Shobra El-khiema, where the coloured effluent was used as the source of yeast isolation in the present study. The samples were kept in sterile glass bottles and preserved at $4^{\circ} \mathrm{C}$ in refrigerator and were tested within 24 $\mathrm{h}$ of the collection time. 


\subsection{Isolation, identification and maintenance of dye degrading yeasts}

Pour plate technique was used for the isolation of dye decolorizing yeast onYeast Extract Peptone Dextrose agar medium (YEPD) (Chen et al., 2002), contains (g/L); glucose, 20; peptone, 20; yeast extract, 10; agar, 20. Well grown yeast colonies were picked and further purified by streaking method. The isolated strains were maintained at $4{ }^{\circ} \mathrm{C}$ on universal agar slants at pH4.7 and contains (g/L); glucose, 10; peptone, 5; yeast extract, 3; malt extract, 3 (Suzuki et al., 1989). Identification of the yeast isolates was carried out using morphological and biochemical characteristics (Barnett et al., 2000) and integral system plus. In addition to ten yeast strains, obtained from Microbiological Resources Center (MIRCEN), Ain shams University, Cairo, Egypt. All yeast strains were tested as dye degrading yeasts.

\subsection{Dye stuff}

Anthraquinone dye (Reactive Brilliant Blue) was obtained from Sigma Aldrich and was employed in this work by dissolving powdered dye stuff in hot ethyl alcohol up to a concentration of $10 \mathrm{mg} / \mathrm{L}$.

\subsection{Screening of dye degrading yeast}

\subsubsection{Inoculum preparation}

Yeasts were individually tested for their growth and decolorization ability on agar medium of pH 5- 6 (Yu and Wen,2005) and contains (g/L): glucose,10; KH2PO4,1; (NH4)2SO4,1; MgSO4.7H2O, 0.5; yeast extract, 0.2 and supplemented with $10 \mathrm{mg} / \mathrm{L}$ of Reactive Brilliant Blue dye and the plates were incubated at $25^{\circ} \mathrm{C}$ till decolorization zone formation and secondary screening was performed with the same procedure on broth medium.

\subsubsection{Dye decolorization experiments}

Dye decolorization experiments were carried out in $50 \mathrm{ml}$ Erlenmeyer flasks containing 10 $\mathrm{ml}$ of broth decolorization medium inoculated with $1 \mathrm{ml}$ of the yeast suspension (OD at $620=0.3$ ) which prepared from an old yeast culture of $18 \mathrm{~h}$. The inoculated flasks were incubated under static aerobic conditions for a period of $24 \mathrm{~h}$ at $25^{\circ} \mathrm{C}$. Uninoculated decolorization medium was also incubated under the same conditions as a control to check abiotic decolorization of the dye. After incubation, the samples were centrifuged for $10 \mathrm{~min}$ at $6000 \mathrm{~g}$ and the decolorization was assesed by measuring the absorbance of the supernatant at $620 \mathrm{~nm}$ (Yu and Wen, 2005). 


\subsubsection{Decolorization assay}

Dye decolorization assay was measured in terms of percentage decolorization using UVspectrophotometer. The percentage was calculated from the following equation, \% Decolorization $=($ Intitial OD- Final OD X 100) / Initial OD

Each decolorization value is the mean of three parallel experiments (Christiane et al., 2013).

\subsection{Optimization of environmental parameters that affect the decolorization process}

Various factors were optimized to achieve the highest decolorization rate of Reactive Brilliant Blue using the selected yeasts. All the experiments were conducted in triplicate.

Decolorization experiment was performed for all the following parameters as described before in 2.4.2

\subsubsection{Temperature}

Decolorization of Reactive Brilliant Blue by the selected yeasts was studied at different temperatures such as $20,25,30,37,45$ and $55^{\circ} \mathrm{C}$. Decolorization medium was used for this purpose containing, $0.1 \mathrm{~g} / \mathrm{L}$ of the dye. Decolorization experiment was performed as described before.

\subsubsection{Incubation time}

The effect of different incubation times 2, 4, 6, 12, 18, 24, 48, 72 and $96 \mathrm{~h}$ were carried out on decolorization efficiency of the selected yeasts. Incubation temperature was at $25^{\circ} \mathrm{C}$ except one yeast strain at $37^{\circ} \mathrm{C}$.

\subsubsection{PH value}

Effect of different $\mathrm{pH}$ values of the medium in ranging from 3 to 6.5 (0.5 intervals) was examined on the decolorization efficiency of the selected yeast strains.The incubation temperature was maintained at $25^{\circ} \mathrm{C}$ except one yeast strain at $37^{\circ} \mathrm{C}$ for $18 \mathrm{~h}$. The $\mathrm{pH}$ was adjusted by using $0.1 \mathrm{~N} \mathrm{HCL}$ and $0.1 \mathrm{~N} \mathrm{NaOH}$ solutions.

\subsubsection{Aerobic and anaerobic conditions}

Aerobic and anaerobic conditions during incubation time of the selected strains were used to find the best condition for maximum decolorization. Two groups of flasks containing decolorization medium that was enriched with $0.1 \mathrm{~g} / \mathrm{L}$ of the dye adjusted at optimum $\mathrm{pH}$ for biodegradation. One group of flasks was incubated under static aerobic condition and the second group was incubated under static anaerobic condition at $25^{\circ} \mathrm{C}$ except one yeast strain at 
$37^{\circ} \mathrm{C}$ for $18 \mathrm{~h}$. Anaerobic conditions were achieved by adding sterile paraffin oil on the surface of the broth medium.

\subsubsection{Inoculum size}

Different inoculum concentrations of $5,10,15,20,25,30,35,40,45$, and $50 \%$

$(\mathrm{v} / \mathrm{v})$ were used to find the best inoculum concentration to achieve the maximum decolorization efficiency. The different inoculum concentrations were added to the decolorization medium $(10 \mathrm{ml})$ containing $0.1 \mathrm{~g} / \mathrm{L}$ of Reactive Brilliant Blue dye .The liquid medium was adjusted at optimum $\mathrm{pH}$ for biodegradation. The flasks were incubated at $25^{\circ} \mathrm{C}$ except one yeast strain at $37^{\circ} \mathrm{C}$ under static aerobic conditions except two yeast strains under anaerobic conditions for $18 \mathrm{~h}$.

\subsubsection{Dye concentration}

Six levels of Reactive Brilliant Blue dye 10, 50, 100, 200, 300 and $500 \mathrm{mg} / \mathrm{l}$ were used to find the best concentration for maximum decolorization. Four $\mathrm{ml}$ of yeast suspension (OD at $620=0.3$ ) were prepared from an old yeast culture of $18 \mathrm{~h}$ and were added to $10 \mathrm{ml}$ of decolorization medium. The flasks were adjusted at optimum $\mathrm{pH}$ for biodegradation and were incubated at $25^{\circ} \mathrm{C}$ except one yeast strain at $37^{\circ} \mathrm{C}$. The flasks were incubated under static aerobic conditions except two yeast strains were incubated under anaerobic conditions for $18 \mathrm{~h}$.

\subsubsection{Carbon source}

In order to assess the effect of different carbon sources on yeast decolorization, four different carbon sources, namely sucrose, lactose, maltose and starch were used by replacing D- glucose in decolorization medium. Four $\mathrm{ml}$ of yeast suspension (OD at620 $=0.3$ ) prepared from an old selected yeast culture and were added to $10 \mathrm{ml}$ of decolorization medium containing $0.01 \mathrm{~g} / \mathrm{L}$ of Reactive Brilliant Blue dye. The flasks were adjusted at optimum $\mathrm{pH}$ for biodegradation and were incubated at $25^{\circ} \mathrm{C}$ except one yeast strain at $37^{\circ} \mathrm{C}$. The flasks were incubated under static aerobic conditions except two yeast strains were incubated under anaerobic conditions for $18 \mathrm{~h}$.

\subsubsection{Nitrogen source}

The effect of five different nitrogen sources yeast extract, peptone, ammonium nitrate, sodium nitrate and Beef extract was examined on the decolorization efficiency of the selected yeast isolates. . Four $\mathrm{ml}$ of yeast suspension $(\mathrm{OD}$ at620 $=0.3$ ) were prepared from an old selected yeast culture of $18 \mathrm{~h}$ and were added to $10 \mathrm{ml}$ of decolorization medium containing 
0.01g/L of Reactive Brilliant Blue dye. The decolorization medium was adjusted at optimum $\mathrm{pH}$ for biodegradation. The flasks were incubated at $25^{\circ} \mathrm{C}$ except one yeast strain at $37^{\circ} \mathrm{C}$. All selected yeasts were incubated under static aerobic conditions except two yeast strains under anaerobic conditions for $18 \mathrm{~h}$.

\subsubsection{Type of medium}

Different types of media; decolorization medium, plain distilled water, distilled water with $5 \%$ glucose and distilled water with $1 \%$ glucose plus $0.1 \%$ peptone plus $0.1 \%$ yeast extract were used to know the best recommended medium for maximum decolorization. Four ml of yeast suspension $(\mathrm{OD}$ at620 $=0.3$ ) were prepared from an old selected yeast culture of $18 \mathrm{~h}$ and were added to $10 \mathrm{ml}$ of decolorization medium containing $0.01 \mathrm{~g} / \mathrm{l}$ of Reactive Brilliant Blue dye. The decolorization medium was adjusted at optimum $\mathrm{pH}$ for biodegradation. The flasks were incubated at $25^{\circ} \mathrm{C}$ except one yeast strain at $37^{\circ} \mathrm{C}$. The flasks were incubated under static aerobic conditions except two yeast strains were incubated under anaerobic conditions for $18 \mathrm{~h}$.

\subsection{Statistical analysis}

All values and data points presented in this work are the means of at least triplicate determinations of independent assays. Data were analyzed using (Two-way ANOVA) twoway analysis of variance (Field, 2013).

\section{Results and Discussion}

\subsection{Results}

\subsection{Screening of dye degrading yeast}

All of the 14 isolates and 10 strains of the yeast were screened for their efficiency to remove anthraquinone. The results indicated that out of the 24 yeasts, 5 yeast isolates $(2,8 \%)$ showed variable potential to decolorize $10 \mathrm{mg} / \mathrm{l}$ Reactive Brilliant Blue in decolorization medium. In addition to the three yeast strains namely; Candida utilis 1, C.sphaerica, Rhodotorula glutinis. Two yeast isolates $(6,7)$ were isolated from the effluent treatment of the textile industry and were identified as Rhodotorula rubra and Cryptococcus albidus. These yeast isolates were selected for further experiments in this study, based on their remarkable abilities to remove this dye color (Table 1). 
Table 1: Decolorization screening on solid and broth media for twenty four yeasts with decolorization medium mixed with Reactive Brilliant Blue $(10 \mathrm{mg} / \mathrm{L})$ grown at $25^{\circ} \mathrm{C}$ for $24 \mathrm{~h}$.

\begin{tabular}{|c|c|c|}
\hline \multirow[t]{2}{*}{ Tested yeast } & Solid medium & Broth medium \\
\hline & Zone decolorization (mm) & Colour reduction \\
\hline Candida utilis(1) & 30 & $+\mathrm{ve}$ \\
\hline Candida utilis(2) & -ve & -ve \\
\hline Candida utilis(3) & -ve & -ve \\
\hline Candida utilis(22) & -ve & -ve \\
\hline Saccharomyces cerevisiae(43) & -ve & -ve \\
\hline Saccharomyces cerevisiae(44) & -ve & -ve \\
\hline Rhodotorula glutinis & 35 & $++\mathrm{ve}$ \\
\hline Candida sphaerica & 60 & $+++\mathrm{ve}$ \\
\hline Candida famata & -ve & -ve \\
\hline Cryptococcus albidus(1) & -ve & -ve \\
\hline Isolate 1 & -ve & -ve \\
\hline Isolate 2 & -ve & -ve \\
\hline Isolate 3 & -ve & -ve \\
\hline Isolate 4 & -ve & -ve \\
\hline Isolate 5 & -ve & -ve \\
\hline Isolate 6 & 38 & $++\mathrm{ve}$ \\
\hline Isolate 7 & 43 & $++\mathrm{ve}$ \\
\hline Isolate 8 & -ve & -ve \\
\hline Isolate 9 & -ve & -ve \\
\hline Isolate 10 & -ve & -ve \\
\hline Isolate 11 & -ve & -ve \\
\hline Isolate 12 & -ve & -ve \\
\hline Isolate 13 & -ve & -ve \\
\hline Isolate 14 & -ve & -ve \\
\hline
\end{tabular}




\subsubsection{Environmental parameters that affect the decolorization process}

\subsubsection{Temperature}

Incubation temperature in a range from 20 to $55^{\circ} \mathrm{C}$ was used to find out the optimal temperature for the decolorization of Reactive Brilliant Blue dye using the selected yeast strains in broth medium. It was observed that an increase in the temperature from 20 to $37^{\circ} \mathrm{C}$ had a significant effect on the decolorization of Reactive Brilliant Blue dye (Fig.1). However, the optimal temperature for decolorization was at $25^{\circ} \mathrm{C}$ for all the tested yeast strains except for Candida utilis (1) was at $37^{\circ} \mathrm{C}$.

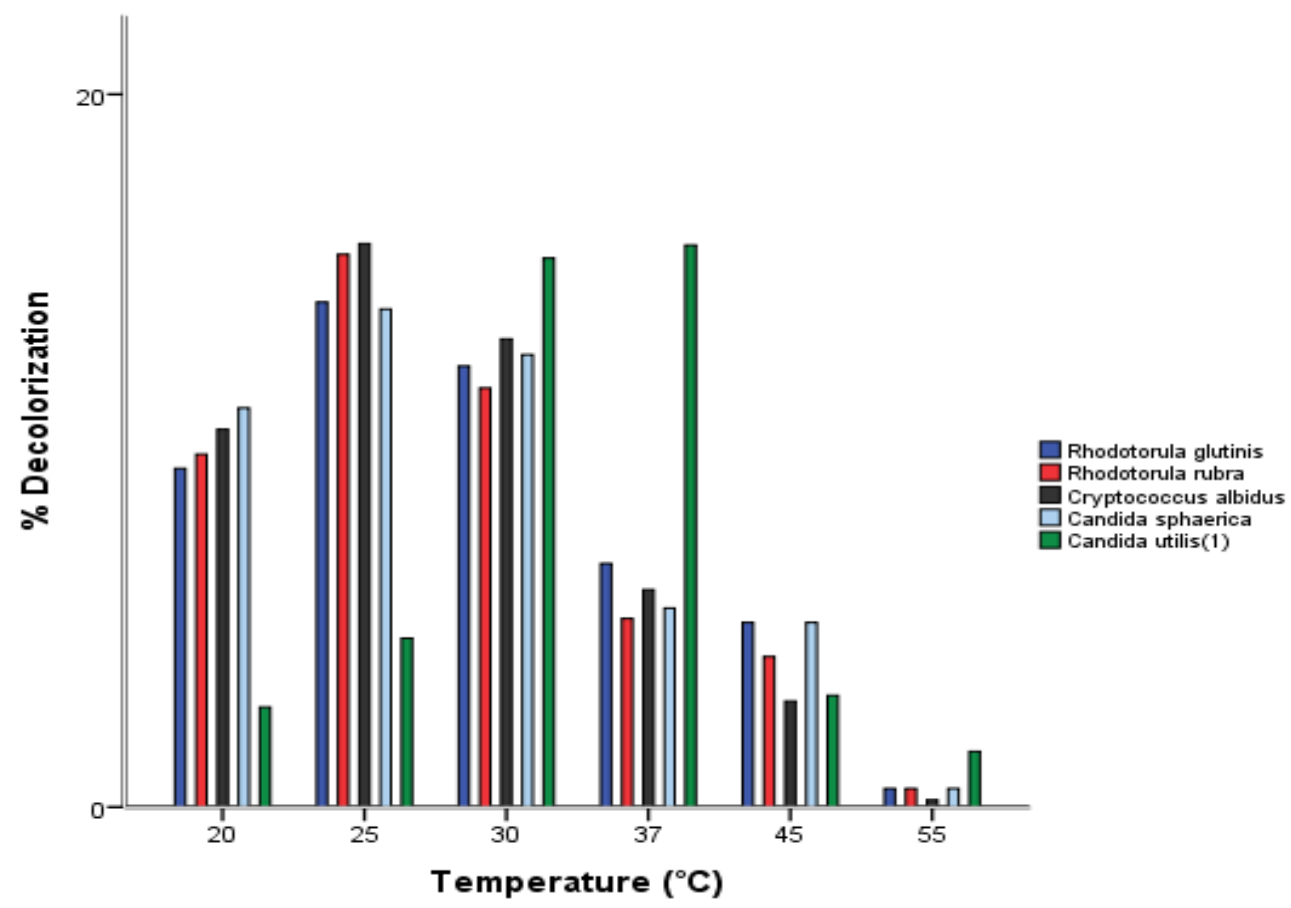

LSD at $5 \% \rightarrow \quad 0.002$

Fig.(1): Effect of incubation temperature on the decolorization by the selected yeast strains 


\subsubsection{Incubation time}

Incubation times in a range from 2 to $96 \mathrm{~h}$ were used to know the optimal incubation time for the decolorization of Reactive Brilliant Blue dye using the selected yeast strains in broth medium (Fig. 2). It was observed that the increase in incubation time from 2 to $18 \mathrm{~h}$ had a significant effect on the decolorization rate of the dye. However, the optimal incubation time to decolorize the dye for all tested strains was $18 \mathrm{~h}$. The decolorization rate in all yeast strains was dropped sharply as the incubation time increased from 24 to $96 \mathrm{~h}$.

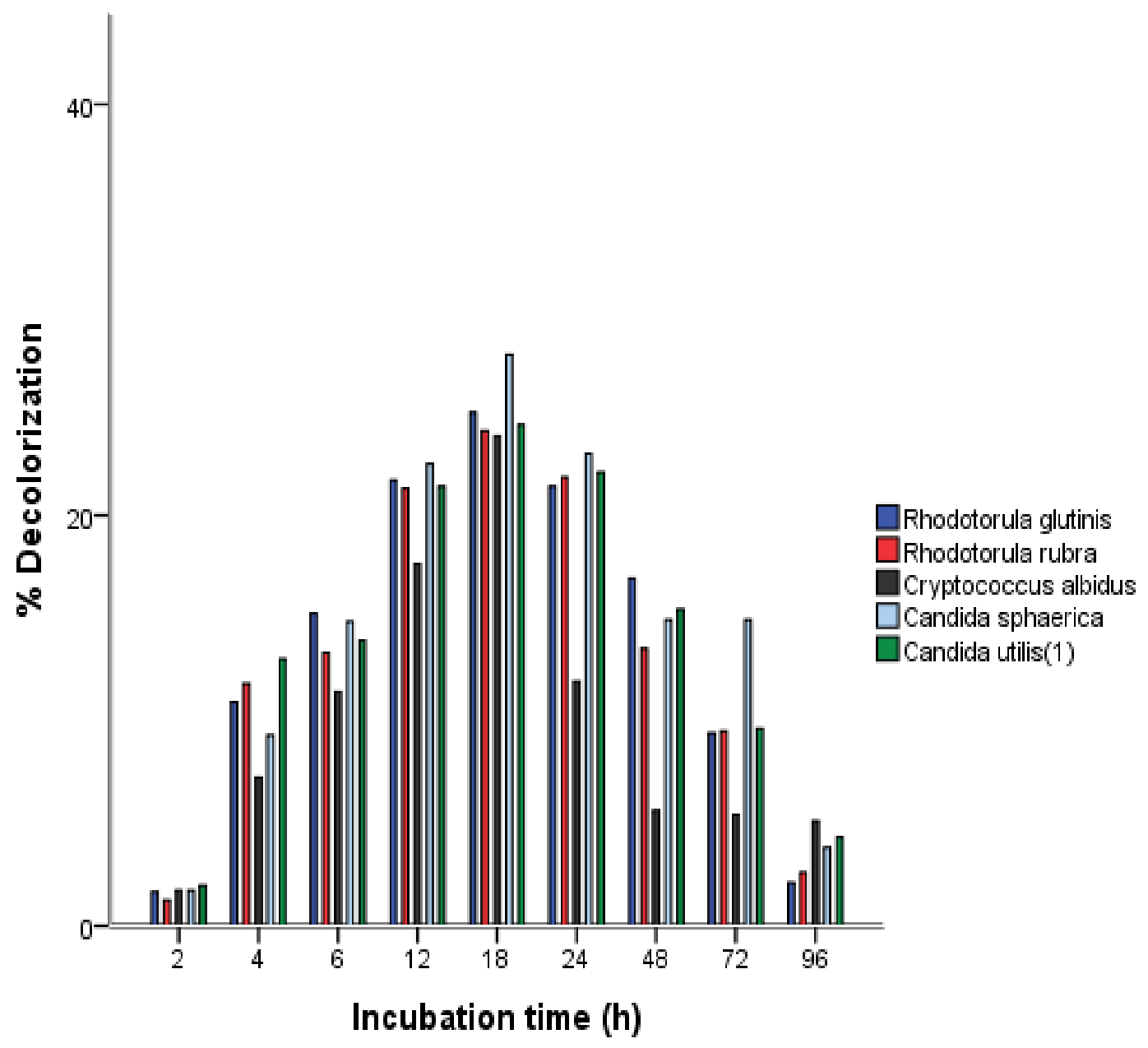

\section{LSD at $5 \% \rightarrow 0.006$}

Fig.(2): Effect of incubation time on the decolorization by the selected yeast strains 


\subsubsection{3. pH value}

PH range from 3 to 6.5 was used to know the optimal $\mathrm{pH}$ value for dye degrading yeasts that achieve the highest decolorization of Reactive Brilliant Blue dye. It was observed that the optimum $\mathrm{pH}$ of the five selected strains was different (Fig. 3). In case of Candida sphaerica, the increase in $\mathrm{pH}$ from 3 to 6 had a significant effect on the decolorization of dye and the optimal $\mathrm{pH}$ for decolorization was at 6 .However, the decolorization rate dropped 6.5. In case of Cryptococcus albidus, Rhodotorula rubra and Candida utilis (1), there was an increase in the rate of decolorization from 3 to 4 and the optimal $\mathrm{pH}$ for decolorization was 4 . While, in case of Rhodotorula glutinis, the optimal pH for decolorization was 5.5.

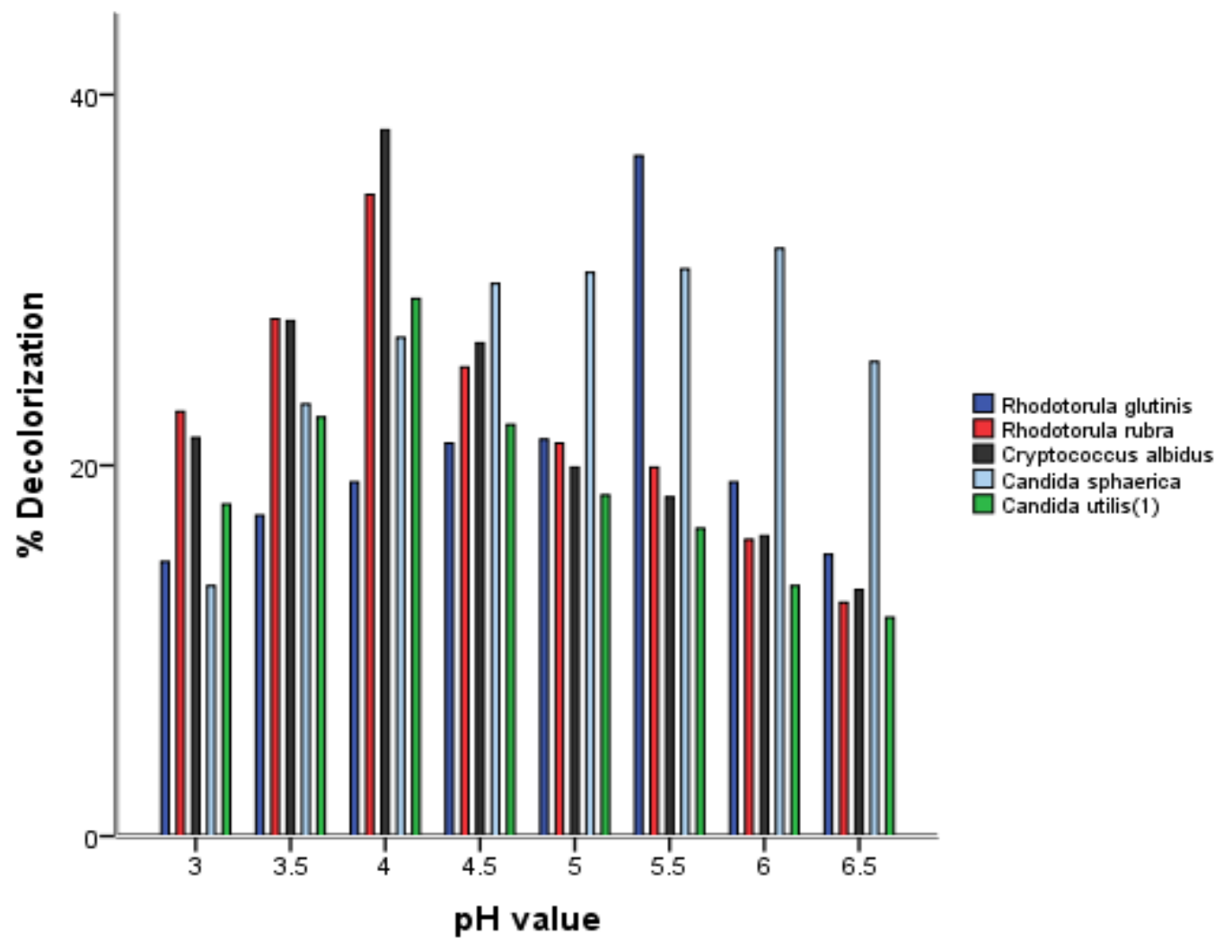

\section{LSD at $5 \% \rightarrow \quad 0.01$}

Fig.(3): Effect of $\mathrm{PH}$ value on decolorization rate 


\subsubsection{Aerobic and anaerobic conditions}

The decolorization rate of Reactive Brilliant Blue dye was increased significantly when Candida sphaerica, Rhodotorula glutinis and Candida utilis(1) were incubated under aerobic conditions. Whereas, the decolorization rate of Cryptococcus albidus and Rhodotorula rubra was increased significantly under anaerobic conditions (fig. 4).

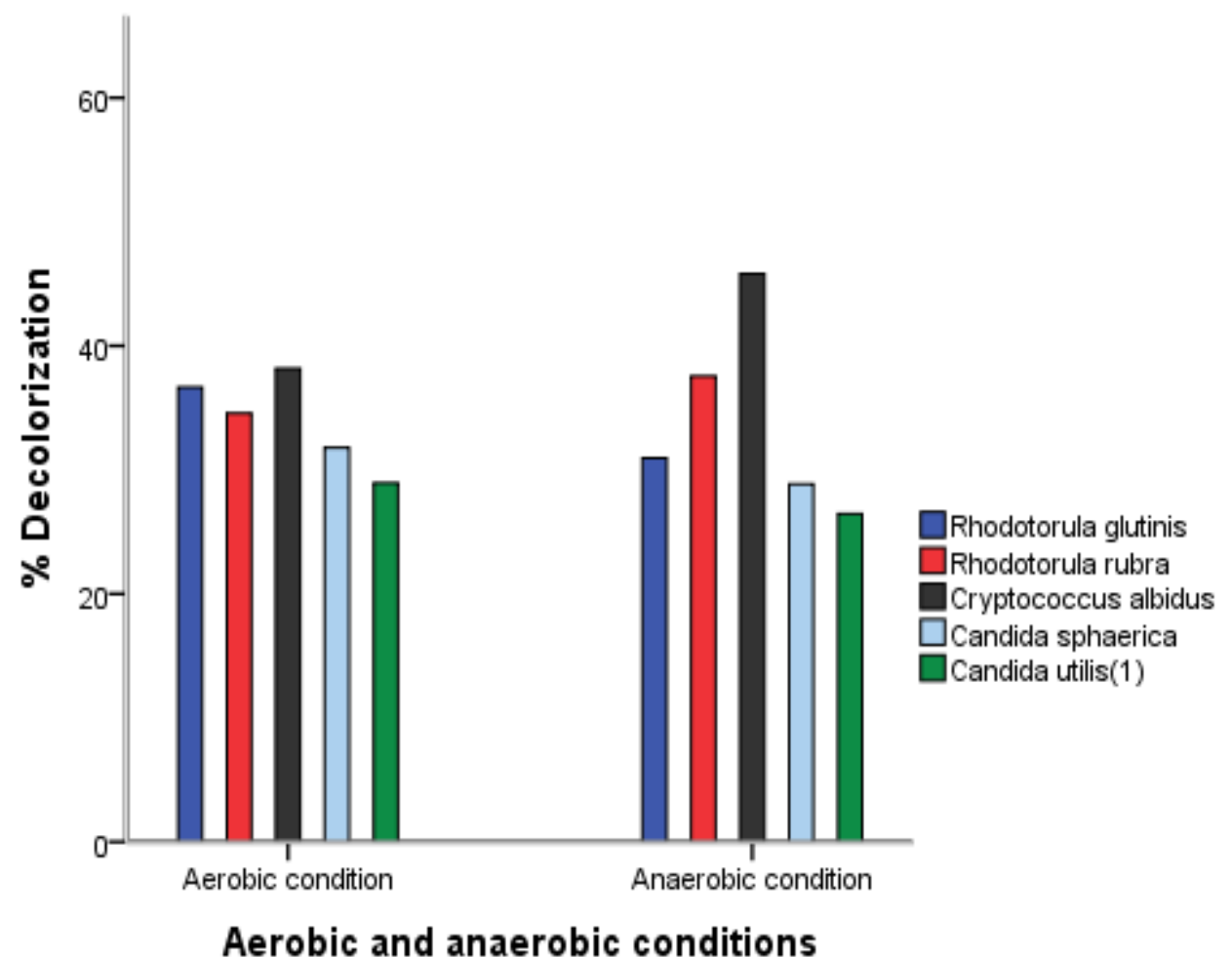

\section{LSD at $5 \% \longrightarrow 0.205$}

Fig.(4): Effect of aerobic and anaerobic conditions of incubation on the decolorization by the selected yeast strains 


\subsubsection{Inoculum size}

From Fig. (5), shows the increasing of inoculum size from 5 to $40 \%(\mathrm{v} / \mathrm{v})$ of all selected yeast strains had a significant increase on the decolorization of Reactive Brilliant Blue dye. However, the optimal inoculum size of all yeast strains to decolorize dye was $40 \%$. The inoculum size has significantly affected the decolorization.

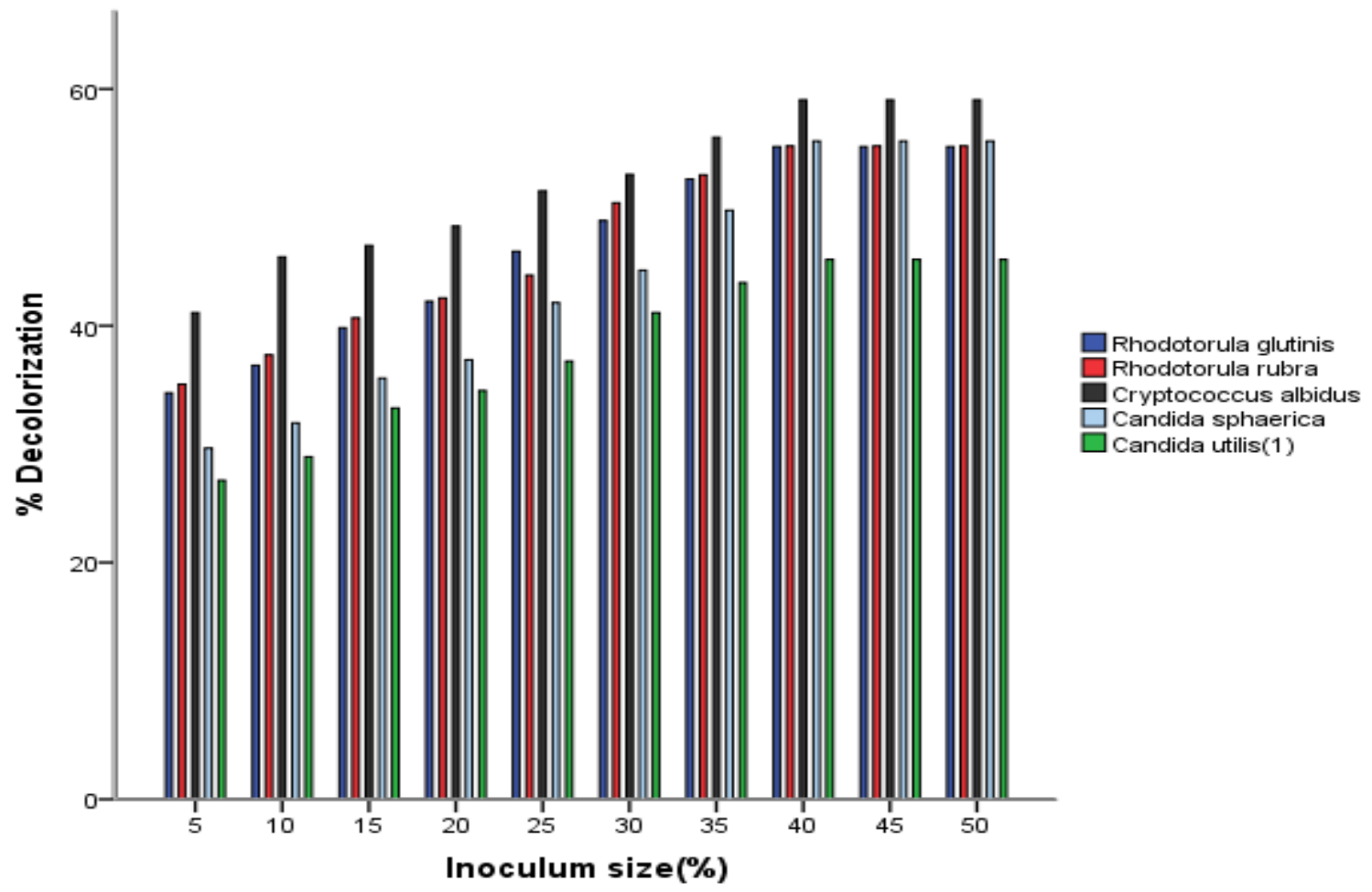

\section{LSD at $5 \% \rightarrow 0.009$}

Fig.(5): Effect of inoculum size on the decolorization bythe selected yeast strains 


\subsubsection{Dye concentration}

The effect of initial concentration of Reactive Brilliant Blue dye on the \% decolorization was investigated and the percentage of decolorization decreased with an increase in the initial concentration (fig. 6). Maximum decolorization was observed at a concentration of $10 \mathrm{mg} / \mathrm{L}$ for all the selected yeast strains. However, decolorization rate in all yeast strains was dropped sharply from 200 to $300 \mathrm{mg} / \mathrm{L}$ but no decolorization was observed at $500 \mathrm{mg} / \mathrm{L}$.Dye concentration significantly has affected the decolorization.

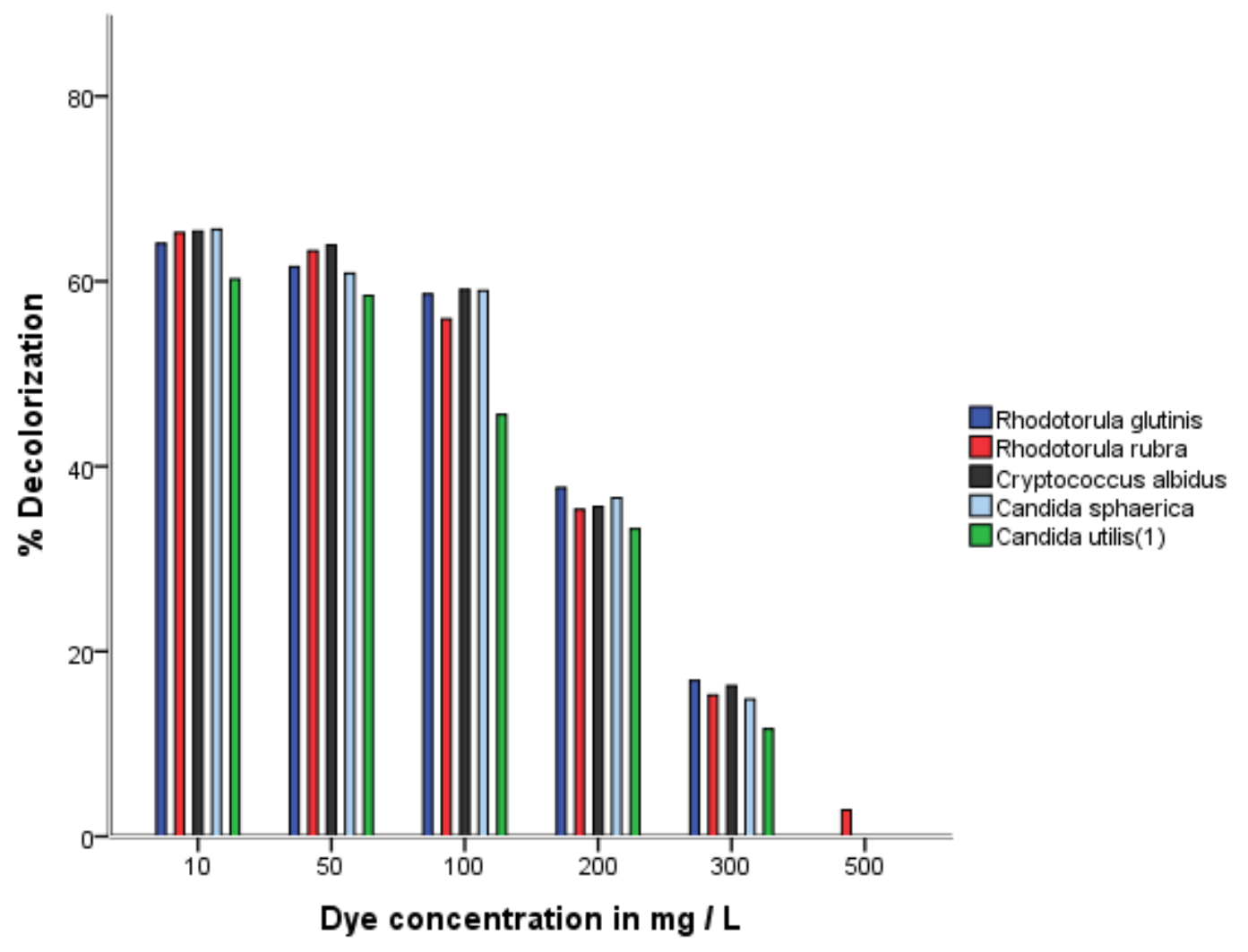

LSD at 5\% $\quad 0.009$

Fig.(6): Effect of dye concentration on the decolorization by the selected yeast strains 


\subsubsection{Carbon source}

The results of decolorization rate indicated that glucose is the best carbon source for all yeasts that decolorize Reactive Brilliant Blue dye (fig.7). However, the rate of decolorization by all the selected yeast strains was lower when starch was supplied as a carbon source.

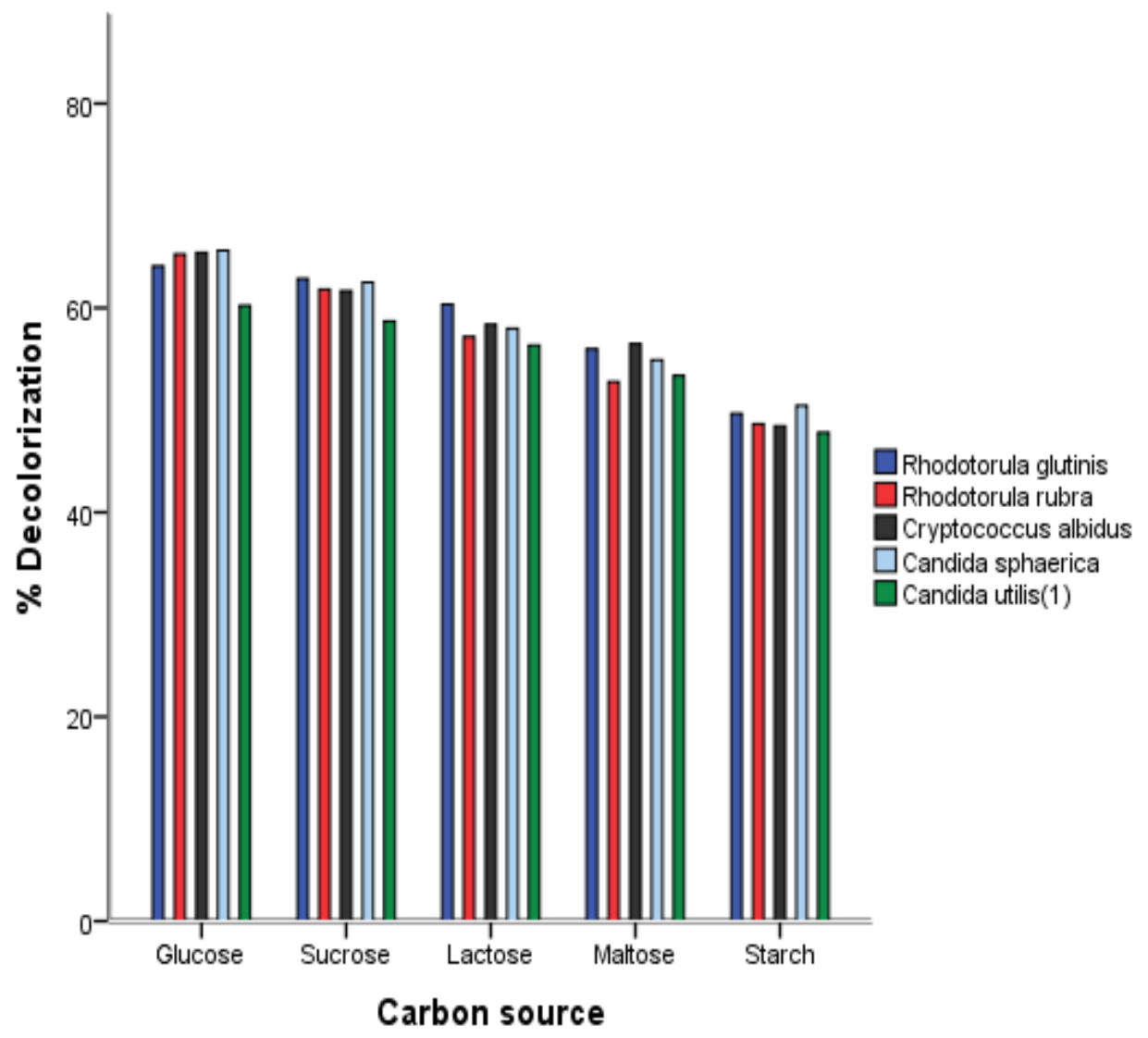

\section{LSD at $5 \% \rightarrow 0.018$}

Fig.(7): Effect of carbon source on the decolorization by the selected yeast strains 


\subsubsection{Nitrogen source}

The results in figure(8) showed that Yeast extract is the optimum and best nitrogen source for decolorization of Reactive Brilliant Blue dye for all the selected yeast strains in comparing with other tested nitrogen sources. However, the decolorization rate in case of other nitrogen sources is different according to the yeast strain.

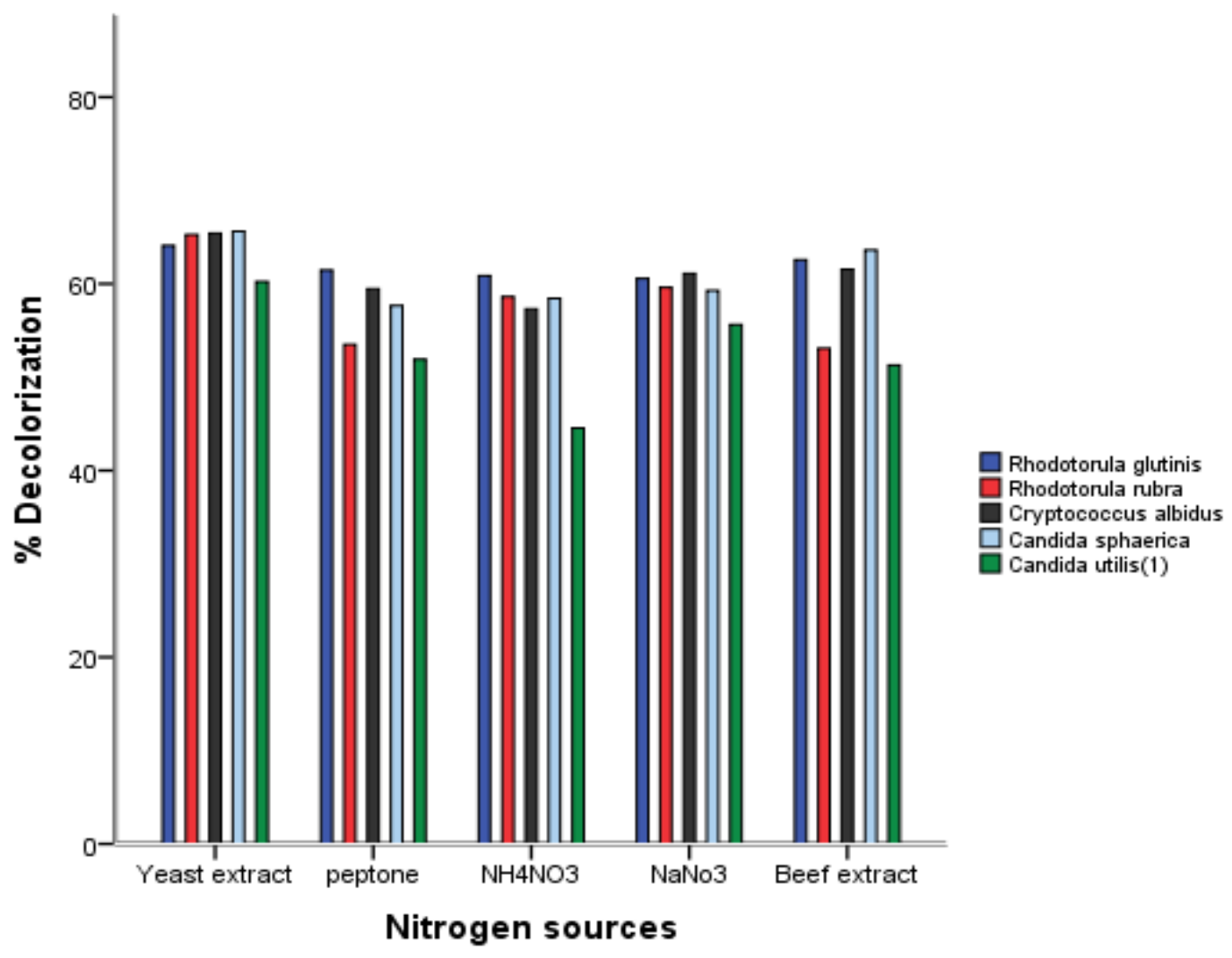

\section{LSD at $5 \% \longrightarrow 0.001$}

Fig.(8): Effect of nitrogen source on the decolorization by the selected yeast strains 


\subsubsection{Type of medium}

Different types of media were used for culturing yeasts to know the best medium composition for the decolorization of Reactive Brilliant Blue dye. All types of used media showed a decolorization of dye. However, the best results were obtained when plain distilled water was used (fig. 9).

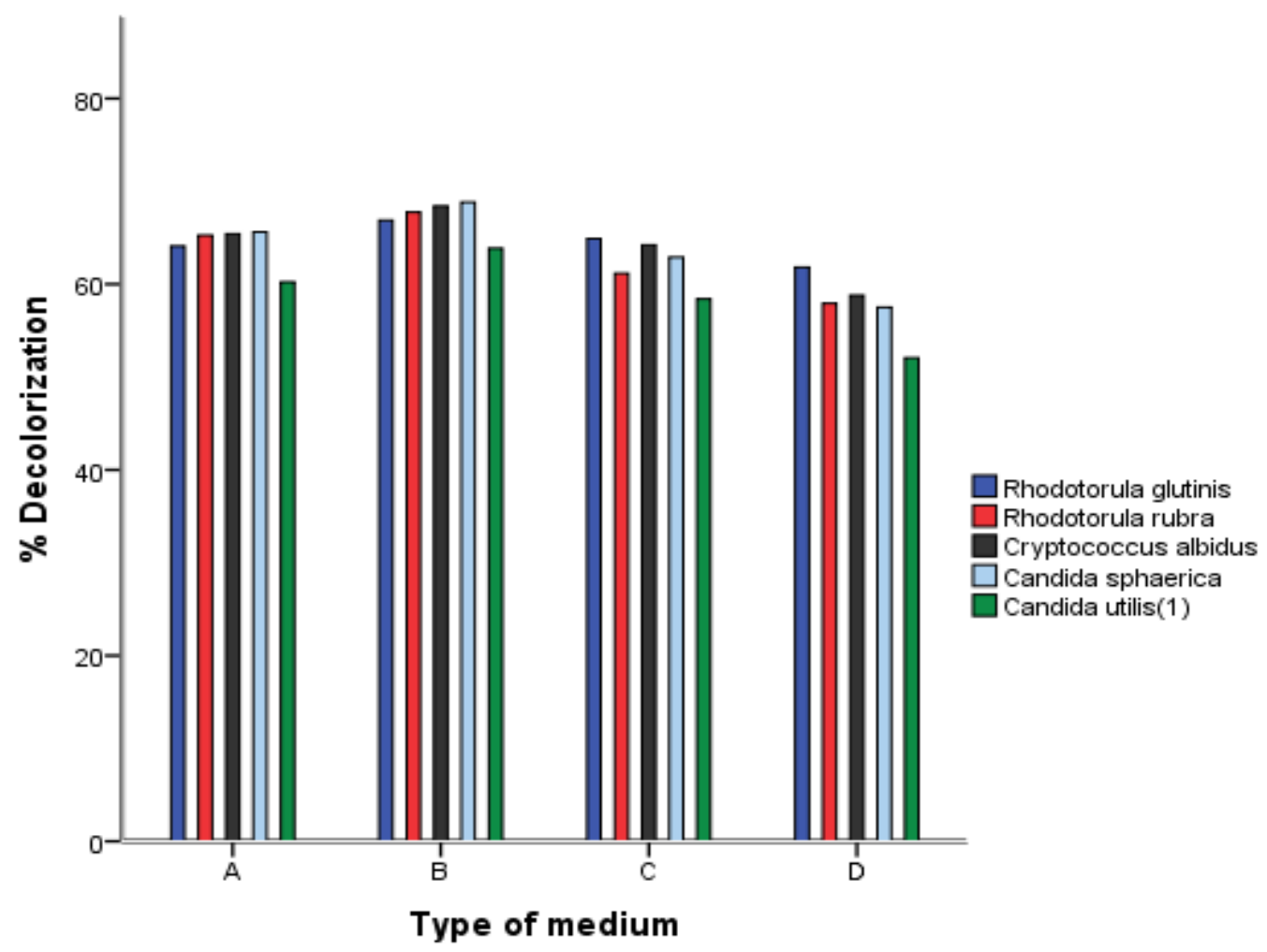

\section{LSD at $5 \% \rightarrow 0.003$}

Fig.(9): Effect of medium composition on the decolorization by the selected yeast strains

Note:

(A)Decolorization medium, (B) plain distilled water, (C) Distilled water with 5\% glucose and (D) Distilled water with $1 \%$ glucose, $0.1 \%$ peptone and $0.1 \%$ yeast extract. 


\subsection{Discussion}

Industrial effluent is not stable and it varies often in a wide range depending upon the process practiced. South Asian countries are experiencing in severe environmental problems due to the rapid industrialization. This phenomenon is very common where the polluting industries like textile dyeing, leather tanning, paper and pulp processing, sugar manufacturing, etc. thrive as clusters. Among these the textile industries are large industrial consumers of water as well as producers of waste water. The effluent discharged by this industry leads to serious pollution of groundwater and soils and ultimately affects the livelihood of the poor (Jiunkins, 1982 and Shah et al., 2013). Some studies have shown that yeast species acted as a promising dye adsorbent capable to uptake higher dye concentration such as Galactomyces getrichum, Saccharomyces cerevisiae and Trichosporon beigilli, etc. (Jadav et al., 2008 and

Lavanya et al., 2014). In this study, out of twenty-four yeast isolates and strains, only five strains $(2.8 \%)$ have the ability to decolorize Reactive Brilliant Blue dye.

Decolorization of Reactive Brilliant Blue by the selected yeast strains was investigated over a temperature range of $25-55^{\circ} \mathrm{C}$. The increase in temperature from 25 to $37^{\circ} \mathrm{C}$ caused an increase in decolorization within $18 \mathrm{~h}$ of incubation. However, further rise in temperature from $37^{\circ} \mathrm{C}$ to onward had negative effect on decolorization of Reactive Brilliant Blue. Decrease in decolorization at higher temperature may be due to the thermal deactivation of the enzyme responsible for decolorization (Shah et al., 2013). It is very likely that all selected yeast strains were mesophilic yeasts because they all showed better decolorization in temperature range of 25 to $37^{\circ} \mathrm{C}$. The mesophilc range is traditionally used since it is generally thought that maintaining high temperature would be uneconomical, while degradation within the psychrophilic range is too slow (Varel et al., 1980). Similar optimum temperature was observed in the decolorization of Remazole black B by Kluyveromyces maxianus IMB3 (Meehan et al., 2000) in case of Candida utilis1 but the remaining strains in contrast with this result.

Textile effluent has alkaline $\mathrm{pH}$ due to substantial presence of salts during dyeing process. High $\mathrm{pH}$ level of textile effluents is one of problems in their biological treatment. Therefore, tolerance to high $\mathrm{PH}$ is important to make this technology valuable (Shah et al., 2013). Another limiting factor for microbial activities and anthraquinone dye decolorization is the $\mathrm{PH}$ of medium. Optimum $\mathrm{pH}$ for growth and decolorization of the selected yeast strains is different. It is very likely that all selected yeast strains were acidophilic yeasts because they all 
showed better decolorization in $\mathrm{pH}$ range of 3 to 6 . It is also likely that $\mathrm{pH}$ might also have affected the enzymatic activity involved in decolorization of dye, in addition to the cellular growth of inocula. It was observed that rate of decolorization increased with increase in inoculum concentration. Maximum rate of decolorization was observed at a $20 \%(\mathrm{v} / \mathrm{v})$ inoculum concentration. There was no proportionate increase of decolorization with increase inoculum concentration when inoculated in textile effluent (Moosvi et al., 2005).

Decolorization rate of all the selected yeast strains was reduced when the concentration of dye was more than $200 \mathrm{mg} / \mathrm{L}$, this might be due to the toxic effect of the dye against the yeast growth or enzymatic activity responsible for the degradation of the dye or inadequate biomass concentration for the uptake of higher concentrations of dye (Jadhav et al., 2007). In literature, the concentrations usually used are less than $0.2 \mathrm{~g} / \mathrm{L}$ (Bibi and Bhatti, 2012; Moreira-Neto et al., 2013). Previous investigations have shown that the dye concentration does affect the rate of biodegradation and the optimum dye level could also vary from microbial species to species and in general higher color removal efficiencies have been observed at medium dye concentrations (Sponza and Isik, 2005; Khalid et al., 2008).

Different carbon and nitrogen sources were investigated for their impact on the decolorization of Reactive Brilliant Blue dye by the selected yeast cultures. Among these glucose and yeast extract supported the highest biodegradation reaction. This observation could be explained that glucose acted as a co-substrate and electron donor which favored the yeast growth and Reactive Brilliant Blue decolorization. In contrast addition of glucose as a carbon source seemed to be effective to promote the decolorization, probably due to the preference of the cells in assimalting the added carbon sources over using the dye compound as the carbon source. Hence the foregoing results suggested that the addition of glucose and yeast extract in synthetic media showed maximum decolorization of Reactive Brilliant Blue by all the selected yeast strains. Similar results of decolorization and biodegradation of textile Navy blue HER by Trichosporon beigelii NCIM-3326 for nitrogen source but in contrast with the results of carbon source (Saratale et al., 2009).

Effect of type of medium on the decolorization of Reactive Brilliant Blue was assessed and the best results were obtained, when distilled water was used as the medium. The results indicate the influence of type of medium and faster biodegradation of Reactive Brilliant Blue than decolorization medium. Similarly the results were obtained by (Jadhav et al., 2007) for the decolorization of azo dye methyl red by Saccharomyces cerevisiae MTCC 463. 


\section{Conclusion}

The present study revealed that the selected five yeasts can be used for decolorizing Reactive Brilliant Blue dye. The cultures exhibited maximum decolorization ability under optimum environmental conditions. The decolorization rate increased up to $69 \%$ in some selected strains. Yeast strains can be further studied for bioremediation of dye-polluted waters including the degradation of anthraquinone dye.

\section{References}

Aksu, Z. and Donmez, G. A, comparative study on the biosorption characteristics of some yeasts for Remazole blue reactive dye. Chemosphere, 50: 1075-1083(2003).

Ayed, L.; Mahdhi, A.; Cheref, A. and Bakhrouf, A., Decolorization and degradation of azo dye methyl red by an isolated Sphingomonas paucimobilis: Biotoxicity and metabolites characterization. Desalination, 274: 272- 277(2011).

Balan, D.S.I. and Monteiro, R.T.R, Decolorization of textile indigo dye by ligninolytic fungi. Journal of Biotechnology, 89: 141- 145 (2001). .

Barnett, J.A.; Payne, R.W. and Yarrow, D., Yeasts, Characteristics and identification, Cambridge: University Press (2000).

Bibi, I. and Bhatti, H.N., Enhanced biodecolorization of reactive dyes by basidiomycetes under static conditions. Applied Biochemistry Biotechnology, 166: 2078- 2090(2012). .

Borchert, M. and Libra, J.A., Decolorization of reactive dyes by the white rot fungus Trameters versicolor in sequencing batch reactors. Biotechnology and Bioengineering, 75: 313- 321(2001).

Chen, K.; Wu, J.; Liou, D. and H Wang, S.J., Decolorization of the textile dyes by newly isolated bacterial strains. Journal of Biotechnology, 101: 57- 68 (2002).

Christiane, A.; Steeve, M.; Jean Bosco, S.T.; Kor, N.M.; Brama, I.; Eric, G. and Philippe, G., Biodegradation of Reactive Blue 4 and Orange $\mathrm{G}$ by Pycnoporus sanguineus strain isolated in Gabon. Bioremediation and Biodegradation,4: 206 (2013). . 
Cristovao, R.O.; Tavares, A.P.M.; Loureiro, J.M.; Boaventura, R.A.R. and Macedo, E.A., Treatment and kinetic modeling of a stimulated dye house effluent by enzymatic catalysis. Bioresource Technology, 100: 6236- 6242 (2009).

Dilek, F.B.; Taplamacioglu, H.M. and Tarlan, E., Color and Aox removal from pulping effluents by algae. Applied Microbiology and Biotechnology,52:581-591(1999).

Dong, X.; Zhou, J. and Liu,Y., Peptone-induced biodecolorization of Reactive Brilliant Blue(KN-R) by Rhodocycus gelatinosus XL-1,process. Biochemistry, 39: 89- 94 (2003).

Field, A.P., Discovering statistics using IBM SPSS statistics and sex and drugs rock n rol $\left(4^{\text {th }}\right.$ Edition) london.sage (2013).

Fu, Y. and Virarahavan, T., Fungal decolorization of dye wastewaters:

A review. Bioresource Technology, 79: 251- 262 (2001).

Gold, M.H. and Alic, M., Molecular biology of lignin-degradaing basidiomycete Phanerochaete chrysosporium. Microbiological Reviews, 57: 605- 622 (1993).

Jadhav, J.P.; Parshetti, G.K.; Kalme, S.D. and Govindwar, S.P., Decolourization of azo dye methyl red by Saccharomyces cerevisiae MTCC463. Chemosphere, 68: 394- 400 (2007).

Jadav, S.U.; Kalme, S.D. and Govindwar, S.P., Biodegradation of methyl red by Galactomyces geotrichum MTCC 1360. International Biodeterioration and Biodegradation, 62: 135-142(2008).

Jiunkins, R., Pretreatment of textile wastewater, proceedings of $37^{\text {th }}$ Industrial waste conference. Purdue university, Lafayette, USA (1982).

Khalid, A.; Arshad, M. and Crowley, D.E., Accelerated decolorization of structurally different azo dyes by newly isolated bacterial strains. Applied Microbiology Biotechnology, 78: 361- 369(2008).

Lavanya, C.; Rajesh, D.; Sunil, C. and Sarita, S., Degeadation of toxic dyes: A review. International Journal of Current Microbiology and Applied Sciences, 6: 189- 199 (2014).

Martorell, M.M.; Pajot, H.F. and Defigueroa, L.I.C., Dye- decolorization yeasts isolated from Las Yungas rain forest.Dye assimilation and removal used as selection criteria. International Biodeterioration and Biodegradation, 66: 25- 32(2012). 
Meehan, C.; Bannat, I.M.; McMullan, G.; Nigam, P.; Smyth, F. and Marchant, R., Decolorization of Remazole Black using a thermotolerant yeast, Kluyveromyces marixanus IBM3. Environment International, 26: 75 - 79 (2000).

Moosvi, S.; Keharia, H. and Madamwar, D., Decolourization of textile dye Reactive Violet 5 by a newly isolated bacterial Consortium RVM11.1. World Journal of Microbiology and Biotechnology, 21: 667- 672 (2005).

Moreira-Neto, S.I.; Mussatto, S.I.; Machado, K.M. and Milagres, A.M., Decolorization of salt-alkaline effluent with industrial reactive dyes by laccase-producing Basidiomycetes strains. Letter Applied Microbiology, 56: 283- 290(2013).

Nigam, P.; Armour, G.; Banat, I.M.; Singh, D. and Marchant, R., Physical removal of textile dyes and solid state fermentation of dye adsorbed agricultureal residues. Bioresource Technology, 72: 219- 226 (2000).

Pajot,H.F. Farina,J.I. and Figueroa,L.I.C., Evidence on manganese peroxidase and tyrosinase expression during decolorization of textile industry dyes by Trichosporon akiyoshidainum. International Biodeterioration and Biodegradation, 65: 1199-1207(2011).

Pajot, H.F.; Delgado, O.D.; Figueroa, L.I.C. and Farina, J.I., Unravelling the decolourizing ability of yeast isolates from polluted and virgin environment: an ecological and taxonomical over review. Antonie Van Leeuwenhoek, 99: 443- 456(2011)

Pavko, A., Fungal decolorization and degradation of synthetic dyes. Some chemical EngineeringAspects. In: Wastewater treatment and Reutilization, Intech, Croatia (2011).

Puvaneswari, N.; Muthukrishnan, J. and Gunasekaran, P., Toxicity assessment and microbial degradation of azo dyes. Indian JEXP Biology, 44: 618-626 (2006).

Robinson, T.; McMullan, G.; Marchant, R. and Nigam, P., Remediation of dyes textile effluent: A critical review on current treatment technologies with a proposed alternative. Biosource Technology, 77: 247- 255(2001).

Sani, R.K. and Banerjee, U.C., Decolorization of triphenylmethane dyes and textile and dye stuff effluent by Kurthia sp. Enzyme and Microbial Technology, 24: 433- 437 (1999). 
Saratale, R.G.; Saratale, G.D.; Chang, J.S. and Govindwar, S.P., Decolorization and Biodegradation of textile dye Navy blue HER by Trichosporon beigelli NCIM 3326. Journal of Hazardous Materials, 166: 1421- 1428 (2009).

Shah, M.P.; Patel, K.A.; Nair, S.S. and Darji, A.M., Optimization of environmental parameters on microbial degradation of Reactive Black dye. Bioremediation and Biodegradation, 4: 3 (2013).

Sudha, M.; Saranya, A.; Selvakumar, G. and Sivakumar, N., Microbial degradation of azo dyes: A review. International Journal ofCurrent Microbiology and Applied Sciences, 3(2): 670- 690(2014).

Sponza, D.T. and Isik,M., Reactor performances and fate of aromatic amines through decolorization of Direct Black 38 dye under anaerobic - aerobic sequentials. Process Biochemistry, 40: 35- 44 (2005).

Suzuki, C.; Yamada, K.; Okada, N. and Nikkuni, S., Isolation and characterization of halo tolerant killer yeasts from fermented foods. Agricultural and Biological Chemistry, 53: 25932597 (1989).

Swamy, J. and Ramsay, J.A., The evaluation of white rot fungi in the decolorization of textile dyes. Enzyme and Microbial Technology, 24: 130- 137 (1999).

Tamboli, D.P.; Kagalkar, A.N.; Jadhav, M.U.; Jadhav, J.P. and Govindwar, S.P., Production of poly hydroxyl hexadecanoic acid by using waste biomass of Sphingo bacterium sp. ATM generated after degradation of textile dye Direct Red 5B. Bioresource Technology, 101: 2421- 2427(2010).

Telke, A.A.; Kalyani, D.C.; Davkar, V.V. and Govindwar, S.P., Influence of organic and inorganic compounds on oxidoreductive decolorization of sulfanated azo dye C.I. Reactive Orange 16. Journal of Hazardous Material, 172: 298-309(2009).

Varel, V.H.; Hashimoto, A.G. and Chen, Y.R., Effect of temperature and retention time on methane production from beef cattle waste. Applied Environmental Micrbiology, 40: 217222(1980). 
Waghmode, T.R.; Kurade, M.B. and Govindwar, S.P., Time-dependent degradation of mixture of structurally different azo and non azo dyes by using Galactomyces geotrichum MTCC 1360. International Biodeterioration and Biodegradation , 65: 479- 486(2011).

Yang, Q.; Tao, L.; Yang, M. and Zhang, H., Effect of glucose on the decolorization of Reactive Black 5 by yeast isolates. Journal of Environmental Science, 20: 105- 108 (2008).

Yu, Z. and Wen, X., Screening and identification of yeast for decolourizing synthetic dyes in industrial wastewater. International Biodeterioration and Biodegradation, 56: 109- 114 (2005).

Zhou,W. and Zimmermann, W., Decolorization of industrial effluents containing reactive dyes by actinomycetes. FEEMS Microbiology Letters, 107: 157-162(1993). 


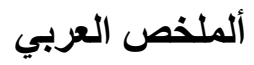

المعايير البيئية المتلي لتحلل صبغ Reactive Brilliant Blue بالخمائر المعزولة من النفايات السائلة لاصباغ

$$
\text { المنسوجات }
$$

سناء محمد عانور ، هدى حسن ابو غالية ، دعاء صابر عبد المقصود الفرماوى

$$
\text { قسم النبات - كلية البنات - جامعه عين شمس }
$$

اجري هذا البحث بغرض دراسة تأثثر دور الخمائر المعزولة من النفايات السامة الناتجة من صناعات الغزل

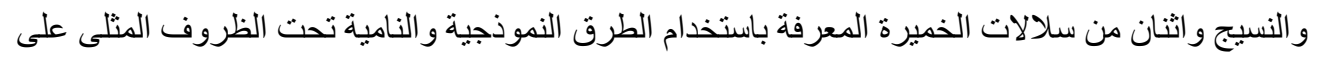
تحليل صبغة Reactive Brilliant Blue.

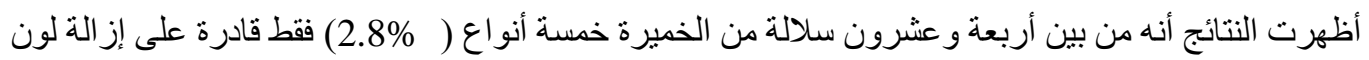

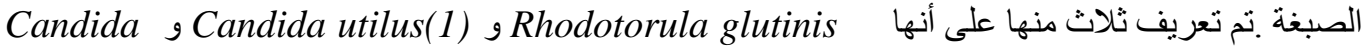

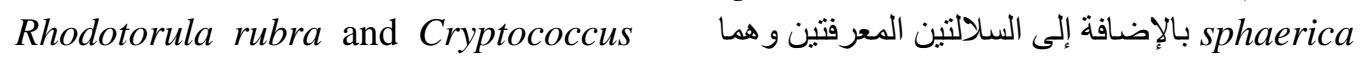

albidus.

تم استخدام السلالات الخمسة في تحليل الصبغة باستخدام بيئة تحتوب على الجلوكوز ومستخلص الخدئ الخميرة كمصدرين لعنصري الكربون و النيتروجين على التوالي ـ وقد لوحظ أن درجة الحر ارة المتلى التى للتحليل التيل الحيوي

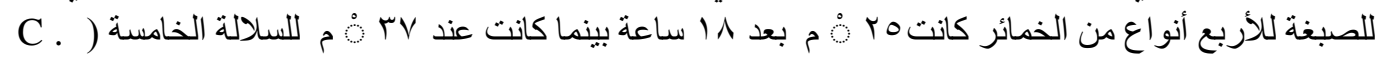
(utilis 1 . وقد كان معامل الأس الهيدروجيني الأمثل مختلف بالنسبة للسلالات المختلفة ، فقد كان معامل

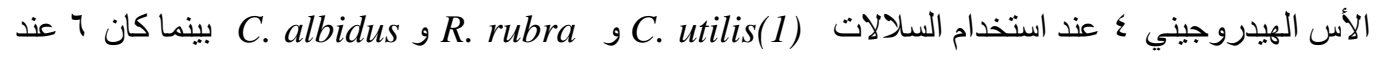

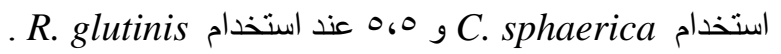

ووجد أن السلالات (1) قد أظهرت معدل عال للتحليل تحت الظروف الهوائية بينما السلالات C. albidus و R. rubra قد أظهرت معدل مرتفع تحت الظروف اللاهو ائية.

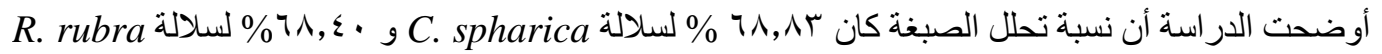

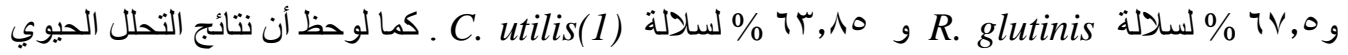
للصبغة كانت معنوية عند استخدام الماء المقطر كبيئة لتحلل الصبغة ه

في الختام، يمكن استخدام سلالات الخمائر للتحلل الحيوي للصبغة الملوثة لمياه الصرف الصناعي منضمنة تحلل صبغة anthraquinone. 